2017-09

Pleistocene range shifts, refugia and the origin of widespread species in Western Palaearctic water beetles.

Garcia-Vazquez, D

http://hdl.handle.net/10026.1/9515

10.1016/j.ympev.2017.06.007

Molecular Phylogenetics and Evolution

Elsevier BV

All content in PEARL is protected by copyright law. Author manuscripts are made available in accordance with publisher policies. Please cite only the published version using the details provided on the item record or document. In the absence of an open licence (e.g. Creative Commons), permissions for further reuse of content should be sought from the publisher or author. 


\section{Pleistocene range shifts, refugia and the origin of 2 widespread species in Western Palaearctic water 3 beetles}

4

5 David García-Vázquez ${ }^{\mathrm{a}}$, David T. Bilton ${ }^{\mathrm{b}}$ Garth N. Foster $^{\mathrm{c}}$, I. Ribera $^{\mathrm{a}^{*}}$

6

7

8

9

10

a Institute of Evolutionary Biology (CSIC-Universitat Pompeu Fabra), Passeig Maritim de la Barceloneta 37, 08003 Barcelona, Spain

${ }^{\mathrm{b}}$ Marine Biology and Ecology Research Centre, Plymouth University, Drake Circus, Plymouth PL4 8AA, UK

${ }^{\mathrm{c}}$ Aquatic Coleoptera Conservation Trust, 3 Eglinton Terrace, Ayr, KA7 1JJ, Scotland, UK

\section{ABSTRACT}

Quaternary glacial cycles drove major shifts in both the extent and location of the geographical ranges of many organisms. During glacial maxima, large areas of central and northern Europe were inhospitable to temperate species, and these areas are generally assumed to have been recolonized during interglacials by range expansions from Mediterranean refugia. An alternative is that this recolonization was from nonMediterranean refugia, in central Europe or western Asia, but data on the origin of widespread central and north European species remain fragmentary, especially for insects. We studied three widely distributed lineages of freshwater beetles (the Platambus maculatus complex, the Hydraena gracilis complex, and the genus Oreodytes), all restricted to running waters and including both narrowly distributed southern endemics and widespread European species, some with distributions spanning the Palearctic. Our main goal was to determine the role of the Pleistocene glaciations in mitochondrial and two nuclear genes in populations drawn from across the ranges of these taxa, and used Bayesian probabilities and Maximum Likelihood to reconstruct their phylogenetic relationships, age and geographical origin. Our results suggest that all extant species in these groups are of Pleistocene origin. In the H. gracilis complex, the widespread European $H$. gracilis has experienced a rapid, recent range expansion from northern Anatolia, to occupy almost the whole of Europe. However, in the other two

shaping the diversification and current distribution of these lineages. We sequenced four 
34 groups widespread central and northern European taxa appear to originate from central 35 Asia, rather than the Mediterranean. These widespread species of eastern origin 36 typically have peripherally isolated forms in the southern Mediterranean peninsulas, 37 which may be remnants of earlier expansion-diversification cycles or result from 38 incipient isolation of populations during the most recent Holocene expansion. The 39 accumulation of narrow endemics of such lineages in the Mediterranean may result 40 from successive cycles of range expansion, with subsequent speciation (and local 41 extinction in glaciated areas) through multiple Pleistocene climatic cycles. 42

43 Keywords: glacial refugia, Dytiscidae, Hydraenidae, Quaternary glaciations, range 44 expansion, Mediterranean Peninsulas, Central Asia 45 46 47 48 


\section{Introduction}

The Quaternary was a period of drastic cyclical climatic changes, with multiple glacial-interglacial periods, ultimately driven by variations in the earth's orbit known as Milankovitch cycles. Milankovitch-driven climate oscillations led to large changes in the size and location of the geographic distribution of many species, in some cases resulting in speciation due to the higher probability of isolation of small populations in areas under new selection regimes (Dynesius \& Jansson, 2000). These Pleistocene climatic oscillations and the subsequent shifts in ecological conditions, with the repeated fragmentation of populations during glacials and interglacials, have long been hypothesised to have driven the origin of most extant Holarctic species (e.g. Rand, 1948; Mayr, 1970).

Pleistocene climatic changes were especially drastic in northern latitudes of the Palearctic region, since during the Last Glacial Maximum the European ice sheet covered most areas north of $52^{\circ} \mathrm{N}$, with permafrost north of $47^{\circ} \mathrm{N}$ (Dawson, 1992). Large areas of central and northern Europe therefore became inhospitable to temperate taxa during glacials; in stark contrast to the Mediterranean peninsulas, which retained more temperate climate and vegetation (e.g. Huntley, 1988; Bennett et al., 1991). However, despite the fact that most of central and northern Europe and regions of Asia at similar latitudes were exposed to extremely cold conditions (Dawson, 1992), there were areas on the slopes of mountain ranges and along river valleys where moister conditions prevailed (Soffer, 1990), allowing the local survival of temperate biota in these northern/eastern refugia (e.g. Stewart et al., 2009; Schmitt \& Varga, 2012).

Two main scenarios could account for the origin of the current central and northern European fauna. Firstly, there is the traditional model of postglacial range expansion from Mediterranean refugia (e.g. Hewitt, 2000), in which central and northern Europe were colonized by northward range expansions mainly from the Iberian, Italian, Balkan and Anatolian peninsulas at the end of the last glaciation. According to this model, populations of most European species were confined to refugial areas in southern Mediterranean peninsulas during glacial maxima, from which they would have re-colonized the continent during interglacials (although Hewitt (2000) also recognised the important role of the Carpathians as providing potential refugia). Whilst such a scenario is well established for some taxa, it is not ubiquitous. A second possibility is that the colonization of central and northern Europe at the end of the Last Glacial was from non-Mediterranean source areas in eastern Europe and Asia (Bilton et 
al., 1998). According to this view, the isolation of the Mediterranean peninsulas during glacial cycles led to speciation, preventing gene flow with the new colonisers of central and northern Europe during subsequent interglacials. For taxa conforming to this model, southern peninsulas are centres of endemism rather than being a source of colonists (Bilton et al., 1998; Schmitt \& Varga, 2012).

Such biogeographical isolation of Mediterranean peninsular populations has been suggested previously for small mammals (Bilton et al., 1998) and some insects (e.g. Cooper et al., 1995). Amongst aquatic Coleoptera, the absence of fossil remains of southern species in the abundant central and northern European Quaternary subfossil record (Abellan et al., 2011) supports a view of Mediterranean peninsulas as areas of endemism, rather than significant sources of postglacial colonists. Data from extant species also suggest that current southern endemics have not contributed to the diversity of northern areas (e.g. Hydrochus (Hydrochidae), Hidalgo-Galiana \& Ribera, 2011; or Enicocerus (Hydraenidae), Ribera et al., 2010). Some central and northern European species may have had their origin in Mediterranean peninsulas, but in such cases it appears that the taxa concerned were those whose refugia were located in the northernmost areas of the peninsulas, on the margins of deglaciated areas (e.g. Ribera et al., 2010 for Enicocerus, and García-Vázquez \& Ribera, 2016 for Deronectes), successful expansion possibly being aided by physiological adaptations in such species (Calosi et al., 2010; Cioffi et al., 2016).

Despite increased understanding of the evolution of the European insect fauna in recent decades, data on the origin of widespread central and northern European species, which should have necessarily experienced recent expansions of their geographical ranges, remain severely limited. Here we study a suite of such species, using molecular phylogeographic data to clarify their temporal and geographic origin and to better understand the role of the Pleistocene glacial cycles in driving their diversification. We examined species groups from three genera of freshwater beetles, in two different families, whose representatives colonised water independently: 1) the Hydraena gracilis complex ("Haenydra" lineage, family Hydraenidae); 2) the Platambus maculatus complex (family Dytiscidae) and (3) Oreodytes sanmarkii (C.R. Sahlberg) and $O$. davisii (Curtis) (family Dytiscidae). All taxa concerned are typical of running waters, and include both widespread European and narrowly distributed southern endemic species (Trizzino et al., 2013; Nilsson \& Hájek, 2017a,b). They do, however, differ in 
116 functional traits and evolutionary histories (see below), facts which contribute to the 117 generality of our conclusions.

118 Using a combination of mitochondrial and nuclear data we reconstruct the

119 phylogenetic relationships, age and geographical origin of the western Palaearctic

120 species of these three widely distributed lineages, to better understand the effects of

121 Quaternary glacial cycles on their diversification and current distributions.

\section{2. Material and Methods}

\section{2.1. Taxonomic background and taxon sampling}

125 a) Hydraena gracilis complex

126 The genus Hydraena, currently with ca. 900 species distributed worldwide

127 (Trizzino et al., 2013) is the largest genus within the family Hydraenidae and probably

128 the most diverse amongst the aquatic Coleoptera (Jäch \& Balke, 2008). Within

129 Hydraena, the "Haenydra" lineage includes ca. 90 species with a north Mediterranean

130 distribution (Trizzino et al., 2013). They are usually found in clean, fast flowing waters,

131 often in mountain streams, from the Iberian Peninsula to Iran and the Urals, but are

132 absent from North Africa (Ribera et al., 2011; Trizzino et al., 2011; Trizzino et al.,

133 2013; Jäch, 2015). Many species of this lineage have very restricted distributions, often

134 limited to a single valley or mountain system, but there are also a few species with very

135 wide geographical ranges.

136 In this work we focus on the most widespread species of "Haenydra", Hydraena

137 gracilis Germar and its closest relatives in the H. gracilis complex sensu Jäch (1995),

138 which includes seven recognised species and one subspecies (Trizzino et al., 2013).

139 Hydraena gracilis is widely distributed across almost the whole of Europe, ranging

140 from southern France eastwards to Ukraine and northwards to Finland, including the

141 British Isles (Fig. 1). Previous molecular studies, albeit on a limited number of

142 specimens (Ribera et al., 2011), suggested that despite its widespread distribution,

143 genetic differences across its geographic range were minimal. Jäch (1995), however,

144 found morphological differences between specimens from the Balkans and the rest of

145 Europe, supporting the recognition of the subspecies $H$. gracilis balcanica

146 d'Orchymont. Hydraena gracilis is absent from the Iberian and Anatolian peninsulas,

147 where it is replaced by different species of the complex (Fig. 1). Hydraena

148 gracilidelphis Trizzino, Valladares, Garrido \& Audisio is the westernmost species of

149 this group, endemic to the Iberian Peninsula (mainly in the north but with some records 
150 in the southwest) and the French Pyrenees (Trizzino et al., 2012). The Anatolian

151 Peninsula and adjacent areas are occupied by three species: H. anatolica Janssens

152 distributed in northern and eastern Anatolia and parts of the Caucasus and northwestern

153 Iran; H. graciloides Jäch in northern Turkey; and H. crepidoptera Jäch known only

154 from two northern Turkish provinces (Kastamonu and Sinop). The other two species of

155 the complex, H. nike Jäch and H. elisabethae Jäch, are endemic to two Aegean islands;

156 Samothraky and Thassos respectively (Trizzino et al., 2013).

157 We studied a total of 48 specimens from five of the seven species of the $H$.

158 gracilis complex (we could not obtain fresh specimens of the two Aegean Island

159 endemics) from 37 different localities, covering the full geographical range of the

160 studied species (Fig. 1; Table S1). As outgroups we used three closely related species of

161 the wider H. gracilis lineage within "Haenydra" (Trizzino et al., 2011; Table S1).

162

163 b) Platambus maculatus complex

164 The genus Platambus contains 66 recognised species (Nilsson \& Hájek, 2017a)

165 and has a wide distribution, being present in the Palearctic, Nearctic, Neotropical and

166 Oriental regions, and is currently divided into eight species-groups (Nilsson \& Hájek,

167 2017a). Amongst these the P. maculatus group - as defined by Nilsson (2001) - is the

168 largest, with 24 species distributed across Asia and Europe. In a molecular phylogeny of

169 Agabinae Ribera et al. (2004) recovered a paraphyletic Platambus, with the $P$.

170 maculatus group separated from other Asian and American species.

171 Here we focus on the most widespread species of the group; P. maculatus

172 (Linnaeus) and its closest relative, P. lunulatus (Fischer von Waldheim), which we refer

173 to as the Platambus maculatus complex. Platambus maculatus has a wide Palearctic

174 distribution, from western Iberia to northern Iran and Mongolia (including Italy, the

175 Balkans and Anatolia), Scandinavia and the British Isles (Nilsson \& Hájek, 2017b; Fig.

176 2). The species has a very variable elytral pattern, which led to the description of many

177 forms all of which are currently considered synonyms of P. maculatus (Nilsson \&

178 Hájek, 2017a,b). Most conspicuous amongst these is P. maculatus "graellsi"

179 (Gemminger \& Harold) from the northwest and centre of the Iberian Peninsula (Millán

180 et al., 2014). The other species of the complex, P. lunulatus, is distributed from the

181 Anatolian Peninsula and parts of the Caucasus and Middle East to Egypt (Karaman et

182 al., 2008; Nilsson \& Hájek, 2017b) (Fig. 2). 

species of the P. maculatus complex, including the "graellsi" form (Fig. 2; Table S1). As outgroups we used seven specimens from different species of the Platambus maculatus group, as defined in Nilsson \& Hájek (2017b).

The Holarctic genus Oreodytes Seidlitz contains 30 recognised species, four of them split into two subspecies (Fery, 2015; Nilsson \& Hájek, 2017a). Oreodytes species live in cold streams or lakes margins, generally at high altitude or latitude (BalfourBrowne, 1940; Zack, 1992; Nilsson \& Holmen, 1995). The genus is distributed in the Palearctic and Nearctic regions, with six species occurring in Europe. In a previous study, Ribera (2003) recovered a paraphyletic Oreodytes, although with low bootstrap support. Oreodytes was divided into two lineages corresponding to the main distinction in body size and shape, i.e. larger and more elongate species (including $O$. davisii) versus smaller and rounder ones (including $O$. sanmarkii).

Of the six European species of Oreodytes, the most widespread is O. sanmarkii, distributed over large parts of the Palearctic from the Iberian Peninsula to the Russian 200 Far East, and reaching the Nearctic in northern Canada (Larson et al., 2000; Nilson \& Hájek, 2017a,b) (Fig. 3). In southern Europe, the species is known from the Iberian

202 Peninsula, northern provinces of Italy and the Balkans south to Bulgaria and Macedonia 203 (Fery, 2015; Nilson \& Hájek, 2017b). The species shows a high level of variability in 204 colouration over its large distributional range (e.g. Larson, 1990) but only one subspecies, O. sanmarkii alienus (Sharp), endemic to the Iberian Peninsula, is currently recognised (Balke, 1989; Nilson \& Hájek, 2017a,b). Also with a wide Palaearctic distribution is $O$. davisii, known from the British Isles to Ukraine and the Caucasus, including Scandinavia, the Mediterranean peninsulas and Turkey (Nilsson \& Hájek, 2017b) (Fig. 3). In the case of this species an Iberian form has also been recognised as a

211 Hájek, 2017a,b). The other European species of Oreodytes are O. septentrionalis

212 (Gyllenhal), distributed from the Iberian Peninsula to eastern Siberia and Mongolia

213 (Nilsson \& Hájek, 2017b); O. alpinus (Paykull), with a northern Palearctic distribution,

214 being present from lochs in northern Scotland (Foster, 1992) and Scandinavia to

215 Kamchatka in the Russian far East (Nilsson \& Kholin, 1994); O. meridionalis Binaghi 
216 \& Sanfilippo, endemic to the southern Apennines (Rocchi 2007; Nilsson \& Hájek, 217 2017b); and the recently described O. angelinii Fery from Greece (Fery, 2015).

218 We studied 58 specimens from 35 different localities of all the European species 219 of Oreodytes with the exception of the Italian endemic O. meridionalis and the newly 220 described $O$. angelinii, with a focus on $O$. davisii and $O$. sanmarkii and the two Iberian 221 subspecies (O.d. rhianae and $O$. s. alienus respectively). We also included in the 222 analysis 16 specimens of different Asian and American species of the genus as 223 outgroups (Fig. 3; Table S1).

\subsection{DNA extraction and sequencing}

Specimens were collected and preserved in absolute ethanol directly in the field.

227 We extracted the DNA non-destructively with commercial kits (mostly "DNeasy Tissue 228 Kit", Qiagen GmbH, Hilden, Germany and "Charge Switch gDNA Tissue Mini Kit", 229 Invitrogen, Carlsbad, CA, USA) following the manufacturers' instructions. Specimens 230 and DNA extractions are deposited in the collections of the Institut de Biología 231 Evolutiva, Barcelona (IBE), Museo Nacional de Ciencias Naturales, Madrid (MNCN) and Natural History Museum, London (NHM). We obtained seven gene fragments from six different genes (four mitochondrial and two nuclear) in five different amplification reactions (see Table S2 for primers and typical sequencing reactions): (1) 5'end of the Cytochrome Oxidase Subunit 1 gene (the barcode fragment; Hebert et al., 2003, COI5'); (2) 3'end of Cytochrome Oxidase Subunit 1 (COI-3'); (3) 5'end of 16S rRNA plus tRNA transfer of Leucine plus 3'end of NADH subunit 1 (nad1) (16S and nad1respectively); and internal fragments of the nuclear genes (4) Histone 3 (H3) and (5) Wingless (Wg). Due to their lower variability, the nuclear markers were only sequenced from representative specimens according to geographical and topological criteria. For each amplification reaction we obtained both forward and reverse

242 sequences. In some specimens, due to difficulties in amplification, we used internal 243 primers for the COI-3' sequence, obtaining two fragments of 400 bp each (Table S2).

244 PCR products were purified by standard ethanol precipitation and sent to external 245 facilities for sequencing. DNA sequences were assembled and edited using the 246 Geneious 6 software (Biomatters Ltd, Auckland, New Zealand). Ambiguous calls in the 247 nuclear genes were coded as "N"s. New sequences (561) have been deposited in 248 GenBank with accession numbers LT855666-LT856230 (Table S2). 
Edited sequences were aligned with MAFFT v.6 using the G-INS algorithm and default values for other parameters (Katoh \& Toh, 2008). We included sequences obtained from the literature (GenBank and BOLD databases) in some analyses to increase geographical coverage and possible genetic variation not covered by our sampling.

In the phylogenetic analyses we employed six partitions, corresponding to the gene fragments COI-5', COI-3', 16S, nad1, H3 and Wg, and used Partition Finder 1.1.1 (Lanfear et al., 2012) to estimate the best-fitting models of nucleotide substitution for each partition separately, using AIC (Akaike Information Criterion). We considered the two fragments of the COI gene separately due to the uneven taxonomic coverage (Table S1). To infer the phylogeny of the three groups, and estimate divergence dates amongst species, we used Bayesian methods implemented in Beast 1.8 (Drummond et al., 2012). For the analyses we included both mitochondrial and nuclear markers and implemented the closest available evolutionary model to those selected by Partition Finder. We used a Yule speciation model and ran two analyses to determine which clock model (strict or lognormal relaxed) best fitted the data. As there are no fossils or unambiguous biogeographic events that could be used to calibrate the phylogeny of the studied groups, we applied published estimations of a-priori rates for the same genes in related groups of beetles. For the Platambus maculatus complex and the genus Oreodytes (both Dytiscidae) we used a rate of 0.013 substitutions/site/MY (SD 0.002) for protein coding genes and 0.0016 substitutions/site/MY (SD 0.0002) for 16S, obtained for the related family Carabidae for the same combination of mitochondrial protein coding and ribosomal genes (Andújar et al., 2012). For the Hydraena gracilis complex we used a rate of 0.015 and 0.006 substitutions/site/MY (SDs 0.002 and 0.0002 ) for the COI3'+nad1 and 16S partitions respectively, obtained for the related Leiodidae (Cieslak et al., 2014). Clock rates of $\mathrm{H} 3$ and $\mathrm{Wg}$ were left with uniform priors due to the absence of any suitable estimations of the evolutionary rate for these nuclear genes. We executed two independent analyses with the same settings, running 100 million generations (saving trees every 5,000) or until analyses converged and the number of trees was sufficient according to Effective Sample Size (ESS) values, as measured with Tracer v1.6 (Rambaut et al., 2014). The maximum clade credibility tree of the two runs was compiled with Tree Anotator v1.8 (Drummond et al., 2012) and visualized with FigTree 
284 clock we used the modified Akaike Information Criterion (AICM) with the moments

285 estimator (Baele et al., 2012), as implemented in Tracer v1.6, with 1,000 bootstrap

286 replicates.

287 To test for potential topological discordances between mitochondrial and nuclear

288 data we analysed the nuclear genes only, applying the best clock and the same settings

289 as in the combined (mitochondrial and nuclear) analysis.

290 We also analysed the combined matrix (mitochondrial and nuclear) using

291 maximum likelihood (ML) methods. ML analyses were performed in RAxML v.7.4.2

292 (Stamatakis et al., 2008) as implemented in RAxML GUI v 1.3.1 (Silvestro \&

293 Michalak, 2012). We selected the best tree out of 100 searches using the GTR+G as an

294 evolutionary model with the same six partitions as in the Bayesian analysis. Node

295 support was estimated with 1,000 bootstrap replicates.

296

297

298

\subsection{Demographic analyses}

To study population history for each of the three groups separately we estimated the population coalescent model that best fitted the data. We used the mitochondrial sequences only and no outgroups. In the analysis for the $H$. gracilis complex we only included specimens of $H$. gracilis and $H$. anatolica, whilst only specimens of $P$. maculatus (including the "graellsi" form) and $O$. sanmarkii were included in the analyses for Platambus and Oreodytes respectively. The datasets were divided into four partitions, corresponding to each mitochondrial gene (COI-5', COI-3', 16S and nad1) and the same settings used as in the topological analyses, including evolutionary models selected by Partition Finder and the best molecular clock for each group. To identify the best demographic model we ran four analyses including Constant Size, Exponential Growth, Logistic Growth and Expansion Growth coalescence models. For model selection of the best coalescent analyses we used the modified Akaike Information Criterion (AICM) with the moments estimator as implemented in Tracer v1.6, with

311 1,000 bootstrap replicates. We also computed Bayesian skyline plots (Drummond et al., 312 2005) for each group, to reconstruct variation in effective population sizes through time.

\section{Results}

There were no length differences in protein coding genes, and the length of

316 ribosomal genes in the ingroup ranged between 784-786 bp in the H. gracilis complex

317 and 796-797 bp in the P. maculatus complex and the genus Oreodytes. The best 
318 evolutionary models, as selected by Partition Finder for each individual partition (Table

319 S3), were implemented in the Bayesian analysis for the $H$. gracilis complex and the 320 species of the genus Oreodytes. In the P. maculatus complex, when the more complex

321 models were applied the analyses did not converge adequately for both the relaxed

322 lognormal and strict clocks, and in consequence we applied an HKY+I+G model to 323 each partition.

\subsection{Hydraena gracilis complex}

The nucleotide alignment matrix showed no variability in the two nuclear genes,

328 lognormal relaxed clock did not converge adequately so we applied a strict molecular 329 clock model.

330 The ultrametric tree obtained with the combined mitochondrial and nuclear data 331 estimated a recent origin and diversification of the $H$. gracilis complex at ca. $0.3 \mathrm{Ma}$ 332 (95\% confidence interval (c.i.) 0.4-0.2 Ma) (Fig. 4), with strongly supported 333 monophyly. The complex was divided into two major clades, one included the Iberian $334 H$. gracilidelphis plus all specimens from the easternmost populations identified as $H$. anatolica (eastern Anatolia, the Caucasus and Iran), and the other was formed by two groups, one containing specimens of $H$. anatolica and $H$. crepidoptera from northern Turkey and the other with the widespread European H. gracilis, including the subspecies $H$. gracilis balcanica and two Turkish specimens of $H$. anatolica and $H$ graciloides. In the latter clade, specimens from the most southeasterly populations occupied basal positions, with the more western and northern populations nested within them (Fig. 4). The lineage with the eastern specimens of $H$. anatolica had a poorly supported position between the two remaining main clades of the complex, which differed between analyses. Bayesian analysis (Fig. 4) recovered the eastern lineage as

344 sister to the Iberian H. gracilidelphis, whilst ML analysis (Fig. S1) linked the eastern

345 lineage to the other clade, as sister to $\mathrm{H}$. gracilis and the Turkish westernmost 346 populations, but always with low support. In the coalescence analyses a constant size model was preferred over exponential growth (Table 1) (logistic and expansion models did not converge adequately). The Bayesian Skyline Plot showed a continuous, slight increase in

350 population size, with a marked increase at ca. 50,000 years BP and a slight decrease 351 towards the present (Fig. 5A). 


\subsection{Platambus maculatus complex}

The relaxed lognormal was significantly better than the strict molecular clock, and was therefore implemented in the Bayesian analyses (Table 1). The temporal origin of the P. maculatus complex was estimated to be in the Middle Miocene (ca. $12 \mathrm{Ma}$ )

357 (Fig. 6), although the split between the two extant species (P. maculatus and $P$.

358 lunulatus) occurred in the Messinian (ca. 6.5 Ma, c.i. 9.3-4.1 Ma). Extant intraspecific 359 variability dates from the Pliocene-Pleistocene boundary (2.5-3.5 Ma). The ultrametric tree obtained from Bayesian analysis using the combined mitochondrial and nuclear matrix strongly supported the monophyly of the two recognised species (Fig. 6).

Platambus maculatus was divided into three clades, one with specimens with a predominantly western distribution (northern Spain, France and the British Isles, including specimens from some Scottish lochs, these forming a monophyletic lineage); a second clade with specimens from easterly populations (central Europe, Scandinavia, the Balkans, Anatolia and the Middle East); and a third clade including specimens of the Iberian "graellsi" form plus P. maculatus from northern Italy and the two sampled specimens from one of the localities in the Pyrenees (PIR11, Fig. 6; Table S1). The relationships between these three lineages were not well supported, and varied between analyses. In the Bayesian analysis using only nuclear markers (Fig. S2), all specimens of P. maculatus "graellsi" plus the northern Italian and PIR11 P. maculatus were included within the western clade. In the ML analysis, on the contrary (Fig. S3), we recovered the northern Italian specimens of $P$. maculatus as sister to all other specimens, which were split into three poorly supported groups (western clade, eastern clade and the "graellsi" form plus the PIR11 P.maculatus referred to above). Skyline Plot showed a nearly constant effective population size until ca. 15,000 years BP, with a recent increase (Fig. 5B).

\subsection{European Oreodytes species}

A relaxed lognormal clock was preferred over a strict molecular clock, and was implemented in the Bayesian analyses (Table 1). Preliminary results showed the existence of two group of species, one closely related to $O$. sanmarkii (the $O$. sanmarkii group) and the other to $O$. davisii (the $O$. davisii group), the later including the 
monophyletic in subsequent Bayesian analyses without outgroups. Oreodytes alpinus was nested within $O$. davisii in the analysis using the combined mitochondrial and nuclear matrix (Fig. 7), forming a clade with the eastern Palaearctic O. mongolicus (Brinck). In the analysis using only nuclear data, O. alpinus and O. mongolicus were also sisters, but both sister to O. davisii (Fig. S4)

Divergence time analysis (Fig. 7) dated the separation between the $O$. davisii and O. sanmarkii groups to the Oligocene (ca. $27 \mathrm{Ma}$, c.i. 36-20 Ma) and diversification within them to the Lower Miocene (ca. $22 \mathrm{Ma}$, c.i. 30-15 Ma) for the $O$. sanmarkii group and the Middle Miocene for the O. davisii group (ca. 13 Ma, c.i. 18-10 Ma) (Fig. 7). The sister species of the clades $O$. davisii $+O$. alpinus $+O$. mongolicus and $O$. sanmarkii were the North American O. snoqualmie (Hatch) and O. obesus (LeConte), respectively. Intraspecific variation in both $O$. davisii and $O$. sanmarkii was of Pleistocene origin (1.5-2.0 Ma) (Fig. 7).

We found no clear phylogeographical signal in $O$. davisii, irrespective of the method of analysis (Bayesian or ML). In contrast, $O$. sanmarkii was divided into two clades with a clear geographical pattern, one including specimens with an eastern distribution, from Mongolia to central Europe, and the other including mainly western specimens, from the Iberian Peninsula, Italy and the British Isles, although also including some individuals from the Carpathians. Within the western clade, Iberian populations from the Pyrenees were separated from those from Portugal and central and northwestern Spain, the latter identified as the subspecies $O$. sanmarkii alienus. This difference was more pronounced in the ML analysis (Fig. S5; although with poor support) and in the analysis using only nuclear data (Fig. S4), which recovered $O$. s. alienus as sister to remaining $O$. sanmarkii.

In the case of other European species of the group, we found a deep divergence between Mongolian and European specimens of O. septentrionalis, estimated to have occurred during the late Miocene (ca. 5.6 Ma, c.i. 8.3-3.5 Ma; Fig. 7). exponential ones (Table 1); the constant size model failing to converge adequately. The

415 Bayesian Skyline Plot showed that effective population size remained constant until relatively recently, with a sharp increase ca. 10,000 years BP (Fig. 5C).

\section{Discussion}


419 Our results emphasise the fact that patterns of evolutionary diversification,

420 biogeographical history and range expansion can differ significantly, even when

421 comparing taxa occupying the same broad habitat type in the same region. The three

422 groups of water beetles examined here have all diversified during the Plio-Pleistocene,

423 and been subject to the same historical climatic shifts, but despite this their colonization

424 history and demography differ considerably.

425

426

427

\subsection{Hydraena gracilis complex}

According to our results the $H$. gracilis complex has a recent, Pleistocene origin, with the widespread $H$. gracilis showing extreme genetic homogeneity throughout its range. This suggests a very recent expansion, in agreement with preliminary results for

430 this and other species of the "Haenydra" lineage (Ribera et al., 2011). The existence of 431 narrow endemics around the periphery of the range of the complex, both in the far west

432 (Iberian Peninsula) and east (Anatolia, Azerbaijan and Iran) is consistent with

433 successive cycles of range expansion within the complex, followed by local extinctions, 434 most likely during the glacial periods. During such times, remaining populations would 435 have been isolated in refuges, resulting in the divergence of $H$. gracilidelphis in the 436 Iberian Peninsula and H. anatolica, H. graciloides and H. crepidoptera in Turkey and 437 the Middle East - a scenario consistent with the model for diversification of this group 438 proposed by Ribera et al. (2011).

439 On current data it was not possible fully to resolve the relationships of eastern

440 Anatolian and Iranian populations of $H$. anatolica, which may be the remnants of earlier 441 diversification cycles (as is the case for H. gracilidelphis in the west) or represent early 442 isolates of the most recent range expansion. The separation between western and eastern 443 populations in $H$. anatolica suggests that the Anatolian Diagonal, a mountain range 444 running from north-eastern to south-western Anatolia, acts as an effective barrier to 445 gene flow between western and eastern regions, a pattern observed in many Turkish 446 taxa (Gündüz et al., 2007). The basal position of northern and central Turkish 447 populations of the $H$. gracilis group suggests a second range expansion from these 448 areas, crossing the straits to the Balkans and expanding to western and northern Europe, 449 resulting in the current widespread European $H$. gracilis. This pattern of expansion has 450 been observed in other taxa, including insects (e.g. grasshoppers, Korkmaz et al., 2014) 451 suggesting that Anatolia was an important glacial refugium, which contributed to the 452 recolonization of Europe in some lineages (Ansell et al., 2011; Hewitt, 1996; Rokas et 
453

al., 2003). Such expansion from Anatolia to the Balkans may have been possible through a substantial decrease in sea level during glacial periods (Aksu et al., 1999; Ergin et al., 2007), which resulted in a large part of the Sea of Marmara becoming dry land through which terrestrial and freshwater taxa may have dispersed.

\subsection{Platambus maculatus complex}

Although the precise geographic origin of the P. maculatus complex remains uncertain, their closest relatives are distributed in eastern and central Asia (Nilsson, 2015; Nilsson \& Hájek, 2017b). Subsequent to the western range expansion from central Asia, one lineage differentiated in Asia Minor and Anatolia, resulting in $P$. lunulatus, and the other Europe, resulting in P. maculatus.

Range expansion in P. maculatus followed a clear geographical pattern, with western and eastern populations falling into two well-supported clades (Fig. 6). An exception here is the uncertain position of specimens from northern Italy and the Iberian "graellsi" form, both of which show appreciable morphological differences in elytral pattern and sculpture. Northern Italian specimens have long been recognised as amongst the largest, most convex and shiny of this species (Sharp, 1882; Balfour-Browne, 1940) (Figs 6, 8), whilst populations from central Iberia were originally described as a distinct species (Agabus glacialis Graells, subsequently changed to A. graellsi), but then reduced to a variety and finally synonymised with P. maculatus (Nilsson \& Hájek, 2017a,b). They have a more reddish coloration than the typical forms of P. maculatus, with a poorly defined colour pattern and a very dense and deep microsculpture, giving their dorsal surface a dull, rough appearance (Sharp, 1882) (Figs 6, 8). Both central Iberian and north Italian populations are at the periphery of the main range of the species, in a situation similar to that for $H$. gracilidelphis and the Iberian Oreodytes (see below). In Platambus our data are, however, inconclusive regarding the origin of these forms, which could have been isolated in the Iberian and Italian Peninsulas as remnants of an earlier range expansion in the complex, or result from incipient isolation during the most recent expansion event.

Within the western clade, specimens from some oligotrophic Scottish lochs, also at the periphery of the species main range, formed a monophyletic lineage. This is most remarkable, as they were, together with $P$. maculatus "graellsi" and the northern Italian populations, the only forms highlighted in the monumental revision of Sharp (1882).

\footnotetext{
Scottish loch animals were described as being the smallest of the species, flatter in
} 
487 shape, with a duller surface and reduced yellow markings on the elytra (Sharp, 1882;

488 Balfour-Browne, 1940) (Figs 6, 8). However, three specimens from Loch Eck, with a 489 similar morphology (although with less marked differences) were not placed in this 490 clade, but amongst other lineages within the wider western clade (Fig. 6; Table S1). We 491 performed additional analyses, including sequences obtained from public databases, to 492 identify specimens with similar haplotypes to those of Scottish lochs, and found a single 493 northern Swedish sequence which nested within the Scottish clade (obtained from 494 Bergsten et al., 2012). The external morphology of this specimen was within the typical 495 range of $P$. maculatus however, and other beetles from the same locality had similar 496 morphology, and COI haplotypes which nested within the western continental lineage.

497 The nuclear markers used did not have enough resolution to determine if such 498 incongruences are the result of introgression, but in any case our results suggest that 499 some Scottish populations, and perhaps others in northern Europe, could be remnants of 500 an early northward range expansion in P. maculatus.

501

\subsection{European species of the genus Oreodytes}

503 Most species of the genus Oreodytes, including the sister species of both $O$.

504 davisii and $O$. sanmarkii (O. snoqualmie and $O$. obesus respectively) are distributed in 505 the western United States and Canada (Larson, 1990; Larson et al., 2000). The 506 geographical origin of European taxa therefore seems to have been via range expansion 507 through Beringia and Asia. In the case of $O$. davisii this expansion has not left any 508 apparent phylogeographical structure in the studied markers. In the combined analyses 509 (largely driven by mitochondrial data) O. alpinus and O. mongolicus were nested within

510 O. davisii, despite considerable morphological differences between these species

511 (Shaverdo \& Fery, 2006; Foster \& Friday, 2011). In contrast, the analysis using only 512 nuclear data clearly separated both species from $O$. davisii, consistent with past 513 mitochondrial introgression between populations of these closely related species who 514 are likely to have shared the same broad Pleistocene refugia. Such a situation has been 515 reported from a number of other taxa (e.g. Berthier et al., 2006; Nichols et al., 2012) 516 including aquatic beetles (Hidalgo-Galiana et al., 2014, García-Vázquez et al., 2016). 517 In $O$. sanmarkii there is a more clearly defined phylogeographic structure, with 518 extant western and eastern clades dating from the middle Pleistocene. This suggests an 519 early origin of European populations, with subsequent isolation of these in different 520 eastern and western refugia. Both $O$. davisii and $O$. sanmarkii are very cold resistant (in 
521 the Pyrenees both can be active in winter in partly frozen streams, I. Ribera unpublished 522 observations), likely able to survive in relatively high northern latitudes during glacial

523 cycles, something which may have favoured local persistence in cryptic northern

524 refugia (see below).

525 Similarly to the $P$. maculatus and $H$. gracilis complexes, the only recognised

526 forms within $O$. davisii and $O$. sanmarkii are the Iberian $O$. davisii rhianae and $O$.

527 sanmarkii alienus respectively, both occurring west and south of the Ebro valley (Balke,

528 1989; Carr, 2001). In the analysis of nuclear data, and also ML analysis of the combined

529 dataset, the sequenced specimens of $O$. sanmarkii alienus formed a monophyletic

530 group, although in a relatively unsupported position with respect to other $O$. sanmarkii.

531 Irrespective of its taxonomic status it seems that $O$. sanmarkii alienus is relatively

532 isolated genetically from other European populations, reinforcing the pattern of

533 peripheral isolation across the ranges of widespread European taxa. Although difficult

534 to assess without molecular data, the two missing European species of Oreodytes in our

535 study, O. meridionalis and $O$. angelinii, are also most likely recent peripheral isolates in

536 Mediterranean peninsulas. Thus, O. meridionalis, from the central and southern

537 Appenines (Rocchi, 2007) was considered to be a synonymy of $O$. davisii by

538 Franciscolo (1979) due to their close external morphology. Similarly, O. angeliini, from

539 northern Greece, has only been recently recognised as a distinct species by Fery (2015),

540 having been considered within the morphological variability of $O$. sanmarkii by

541 previous authors.

542

543 4.4. Concluding remarks: routes of recolonization

544 Our results show that for some water beetles, as in many other groups, central 545 and northern Europe were recolonized by range expansions from peripheral refugia at

546 the end of the last glaciation. Northern areas of Iberia and Anatolia appear particularly

547 relevant for the taxa studied here, both as sources of recolonists and as cradles for

548 recent, narrow-range endemics. In addition to this classic pattern, however, we also

549 show that some widespread central and northern European species originated not around

550 the Mediterranean basin, but in central Asia, although such taxa still have peripherally

551 isolated forms in the southern Mediterranean peninsulas that in some cases possess

552 divergent haplotypes from those in central and northern Europe. Such species may have

553 colonized northern areas of the continent from cryptic refugia in central/eastern Europe

554 or western Asia during the Holocene. Of particular interest is the possibility of 
555 peripheral refugia not only in the Mediterranean region but also in some areas in the 556 north, as suggested by the Scottish form of $P$. maculatus.

557 Glacial refugia during cold episodes in Europe were not restricted to the three 558 southern peninsulas, as shown by multiple examples from the Carpathians (Willis et al., 559 2000; Deffontaine et al., 2005; Kotlík et al., 2006; Sommer \& Nadachowski, 2006), and 560 other areas in north and central Europe (Kullman, 1998; Bilton et al., 1998; Stewart \& 561 Lister, 2001). Quaternary deposits suggest that a woodland zone existed in the southern 562 foothills of the Carpathian mountains and in sheltered valleys at mid elevations, even 563 during the LGM (Lozek, 2006; Willis et al., 2000). More easterly areas could have also 564 been involved in the colonization of Europe from Asia, including the Caucasus 565 (Massilani et al., 2016). Other potential refugia may have been situated in the Urals, the 566 northern slopes of the Altai, or the Crimean Peninsula (Grichuk, 1984; Hewitt, 1999;

567 Soffer 1990) as well parts of the Ukraine and European Russia (Tarnowska et al., 2016). 568 In the case of the species studied here, as with other European lotic water beetles 569 (García-Vázquez \& Ribera, 2016), interglacial range expansions did not result in the 570 mixing and homogenisation of gene pools, but instead drove the isolation and 571 differentiation of populations at range edges. All the running water beetle lineages 572 studied here are relatively weak dispersers compared to most standing water relatives.

573 All P. maculatus examined by Jackson $(1952,1956)$ had reduced flight muscles and 574 most studied specimens of $O$. sanmarkii have reduced flight muscles, although there is 575 at least one record of a specimen with these fully developed (Foster et al., 2016). $O$. 576 davisii and H. gracilis are known to fly (Jäch, 1997; Foster et al., 2016) although have 577 been recorded doing so relatively rarely. It is interesting, however, that these two 578 species are the most genetically homogeneous of the species studied here. This 579 relatively poor dispersal ability beggs the question as to how some species are able to 580 expand their ranges to continental scales? The relative genetic homogeneity of 581 widespread species, with genetic differentiation only in peripheral isolates, together 582 with our coalescence data, suggest rapid range expansions over short temporal windows 583 which may have provided optimal ecological conditions for movement between habitat 584 patches. Recently deglaciated areas are likely to have supported a high density of lotic 585 environments, something which may have facilitated the expansion of these beetles. In 586 the Massif Central, Ponel et al. (2016) found an increase in fossil remains of lotic water 587 beetle species immediately after the Last Glacial, but also following the Younger Dryas. 588 This abundance of lotic species was associated with an increase in stream flow resulting 
589 from snow melt during the rapid warming following these two cold periods. When soil 590 formation and sedimentation transformed the landscape, the abundance of lotic species 591 decreased in parallel with an increase in lentic taxa (Ponel et al., 2016). If the same 592 habitat succession happened at larger geographical scales across the continent, it would 593 have facilitated rapid range expansions in lotic species living close to the margins of 594 deglaciated areas, but only for a short time period. As conditions changed, many 595 populations are likely to have become locally extinct, precipitating the genetic isolation 596 of the remainder and in some their eventual speciation (Ribera et al., 2011). The 597 accumulation of narrowly endemic species in lotic lineages may result from successive 598 cycles of range expansion with subsequent speciation and local extinction in glaciated 599 areas over multiple Pleistocene glacial cycles.

600

601 Acknowledgements

602 We thank all the collectors in Table S1 for allowing us to study their material, and Ana 603 Izquierdo (MNCN) and Rocío Alonso (IBE) for laboratory work. We also thank J.

604 Bergsten for providing voucher specimens of Swedish P. maculatus for study, U.

605 Schmidt and L. Borowiec for some of the habitus photographs, and two anonymous

606 Referees for comments. DG-V had a FPI PhD grant from the Spanish Government. This 607 work was partially funded by projects CGL2010-15755 and CGL2013-48950-C2-1-P 608 (AEI/FEDER, UE) to IR, and the "Secretaria d'Universitats i Recerca del Departament 609 d'Economia i Coneixement de la Generalitat de Catalunya'” (project SGR1532).

\section{References}

612

613 Abellán, P., Benetti, C.J., Angus, R.B., Ribera, I., 2011. A review of Quaternary range 614 shifts in European aquatic Coleoptera. Glob. Ecol. Biogeogr. 20, 87-100.

615 Aksu, A.E., Hiscott, R.N., Yaşar, D., 1999. Oscillating Quaternary water levels of the 616 Marmara Sea and vigorous outflow into the Aegean Sea from the Marmara Sea617 Black Sea drainage corridor. Mar. Geol. 153, 275-302.

618 Andújar, C., Serrano, J., Gómez-Zurita, J., 2012. Winding up the molecular clock in the 619 genus Carabus (Coleoptera: Carabidae): assessment of methodological decisions 620 on rate and node age estimation. BMC Evol. Biol. 12, 1.

621 Ansell, S. W., Stenøien, H. K., Grundmann, M., Russell, S. J., Koch, M. A., Schneider, 622 H., Vogel, J. C., 2011. The importance of Anatolian mountains as the cradle of 
623

624

625

626

627

628

629

630

631

632

633

634

635

636

637

638

639

640

641

642

643

644

645

646

647

648

649

650

651

652

653

654

global diversity in Arabis alpina, a key arctic-alpine species. Ann. Bot. 108, 241252.

Baele, G., Lemey, P., Bedford, T., Rambaut, A., Suchard, M.A., Alekseyenko, A. V, 2012. Improving the accuracy of demographic and molecular clock model comparison while accommodating phylogenetic uncertainty. Mol. Biol. Evol. 29, 2157-2167.

Balfour-Browne, F., 1940. British water beetles. Vol. 2. Ray Society, London.

Balke, M., 1989. Zur identität von Hydroporus alienus Sharp, 1872 (Coleoptera, Dytiscidae). Elytron 3, 113-114.

Bennett, K.D., Tzedakis, P.C., Willis, K.J., 1991. Quaternary refugia of north European trees. J. Biogeogr. 18, 103-115.

Bergsten, J., Bilton, D.T., Fujisawa, T., Elliott, M., Monaghan, M.T., Balke, M., Hendrich, L., Geijer, J., Herrmann, J., Foster, G.N., Ribera, I., Nilsson, A.N., Barraclough, T.G., Vogler, A.P. 2012. The effect of geographical scale of sampling on DNA barcoding. Syst. Biol. 61, 851-869.

Berthier, P., Excoffier, L., Ruedi, M., 2006. Recurrent replacement of mtDNA and cryptic hybridization between two sibling bat species Myotis myotis and Myotis blythii. Proc. R. Soc. London B Biol. Sci. 273, 3101-3123.

Bilton, D.T., Mirol, P.M., Mascheretti, S., Fredga, K., Zima, J., Searle, J.B., 1998. Mediterranean Europe as an area of endemism for small mammals rather than a source for northwards postglacial colonization. Proc. R. Soc. London B Biol. Sci. 265, 1219-1226.

Calosi, P., Bilton, D.T., Spicer, J.I., Votier, S.C., Atfield, A., 2010. What determines a species' geographical range? Thermal biology and latitudinal range size relationships in European diving beetles (Coleoptera: Dytiscidae). J. Anim. Ecol. 79, 194-204.

Carr, R., 2001. Oreodytes davisii rhianae subsp. nov. (Coleoptera: Dytiscidae): an Iberian subspecies distinct from $O$. davisii davisii (Curtis, 1831). Entomol. Gaz. 52, 183-188.

Cieslak, A., Fresneda, J., Ribera, I., 2014. Life-history specialization was not an evolutionary dead-end in Pyrenean cave beetles. Proc. R. Soc. London B Biol. Sci. 281, 20132978. 
Cioffi, R., Moody, A.J., Millán, A., Billington, R.A., Bilton, D.T., 2016. Physiological niche and geographical range in European diving beetles (Coleoptera: Dytiscidae). Biol. Lett. 12, 20160130.

Cooper, S.J.B., Ibrahim, K.M., Hewitt, G.M., 1995. Postglacial expansion and genome subdivision in the European grasshopper Chorthippus parallelus. Mol. Ecol. 4, 4960.

Dawson, A.G., 2013. Ice age Earth: late quaternary geology and climate. Routledge, New York.

Deffontaine, V., Libois, R., Kotlík, P., Sommer, R., Nieberding, C., Paradis, E., Searle, J.B., Michaux, J.R., 2005. Beyond the Mediterranean peninsulas: evidence of central European glacial refugia for a temperate forest mammal species, the bank vole (Clethrionomys glareolus). Mol. Ecol. 14, 1727-1739.

Drummond, A.J., Rambaut, A., Shapiro, B., Pybus, O.G., 2005. Bayesian coalescent inference of past population dynamics from molecular sequences. Mol. Biol. Evol. 22, 1185-1192.

Drummond, A.J., Suchard, M.A., Xie, D., Rambaut, A., 2012. Bayesian phylogenetics with BEAUti and the BEAST 1.7. Mol. Biol. Evol. 29, 1969-1973.

Dynesius, M., Jansson, R., 2000. Evolutionary consequences of changes in species' geographical distributions driven by Milankovitch climate oscillations. Proc. Natl. Acad. Sci. USA. 97, 9115-9120.

Ergin, M., Uluadam, E., Sarikavak, K., Keskin, Ş., Gökaşan, E., Tur, H., 2007. Late Quaternary sedimentation and tectonics in the submarine Şarköy Canyon, western Marmara Sea (Turkey). Geol. Soc. London, Spec. Publ. 291, 231-257.

Fery, H., 2015. Oreodytes angelinii, a new species from north-eastern Greece (Coleoptera: Dytiscidae: Hydroporinae). Klapalekiana 51, 39-47.

Foster, G.N., 1992. Some aquatic Coleoptera from inner Hordaland, Norway. Fauna Norv. Ser. B. 39, 63-67.

Foster, G.N., Bilton, D.T., Nelson, B.H. 2016. Atlas of the predaceous water beetles (Hydradephaga) of Britain and Ireland. FSC Publications, Telford, UK.

Foster, G.N., Friday, L.E., 2011. Key to adults of the water beetles of Britain and Ireland (Part 1). Handbook for the Identification of British Insects. Vol. 4, Part 5. F. Stud. Counc. R. Entomol. Soc. London, London.

Franciscolo, M.E., 1979. Fauna d'Italia, Vol. XIV: Coleoptera. Haliplidae, Hygrobiidae, Gyrinidae, Dytiscidae. Edicioni Calderini, Bologna. 
689 García - Vázquez, D., Bilton, D.T., Alonso, R., Benetti, C.J., Garrido, J., Valladares,

690 L.F., Ribera, I., 2016. Reconstructing ancient Mediterranean crossroads in

691 Deronectes diving beetles. J. Biogeogr. 43, 1533-1545.

692 García-Vázquez, D., Ribera, I., 2016. The origin of widespread species in a poor

693 dispersing lineage (diving beetle genus Deronectes). PeerJ 4, e2514.

694 Grichuk, V.P., 1984. Late Pleistocene vegetation history. In: Velichko, A.A., Wright Jr,

695 H.E., Barnosky, C.W. (Eds.), Late Quaternary environments of the Soviet Union.

696 Longman, London, pp. 155-178..

697 Gündüz, İ., Jaarola, M., Tez, C., Yeniyurt, C., Polly, P.D., Searle, J.B., 2007.

698 Multigenic and morphometric differentiation of ground squirrels (Spermophilus,

699 Scuiridae, Rodentia) in Turkey, with a description of a new species. Mol.

$700 \quad$ Phylogenet. Evol. 43, 916-935.

701 Hebert, P.D.N., Ratnasingham, S., de Waard, J.R., 2003. Barcoding animal life:

$702 \quad$ cytochrome c oxidase subunit 1 divergences among closely related species. Proc.

703 R. Soc. London B Biol. Sci. 270, S96-S99.

704 Hewitt, G.M., 1996. Some genetic consequences of ice ages, and their role in

705 divergence and speciation. Biol. J. Linn. Soc. 58, 247-276.

706 Hewitt, G.M., 1999. Post- glacial re- colonization of European biota. Biol. J. Linn. Soc.

$707 \quad 68,87-112$.

708 Hewitt, G., 2000. The genetic legacy of the Quaternary ice ages. Nature 405, 907-913.

709 Hidalgo-Galiana, A., Ribera, I., 2011. Late Miocene diversification of the genus

710 Hydrochus (Coleoptera, Hydrochidae) in the west Mediterranean area. J Biogeogr

$71159,377-385$.

712 Hidalgo-Galiana, A., Sánchez-Fernández, D., Bilton, D.T., Cieslak, A., Ribera, I., 2014.

713 Thermal niche evolution and geographical range expansion in a species complex of

$714 \quad$ western Mediterranean diving beetles. BMC Evol. Biol. 14, 187.

715 Huntley, B., 1988. Glacial and Holocene vegetation history: Europe. Veg. Hist. 341716383.

717 Jäch, M.A., 1995. The Hydraena (Haenydra) gracilis Germar species complex (Insecta:

718 Coleoptera: Hydraenidae). Ann. Naturhist. Mus. Wien. 97B, 177-190.

719 Jäch, M.A., 1997. Daytime swarming of rheophilic water beetles in Austria (Coleoptera:

720 Elmidae, Hydraenidae, Haliplidae). Latissimus 9, 10-11. 
Jäch, M.A., 2015. Hydraenidae. In: Löbl, I., Löbl, D. (Eds.), Catalogue of Palaearctic Coleoptera, 2nd ed. Volume 2/1: Hydrophiloidea - Staphylinoidea.. Brill, Leiden, pp. 130-162.

Jäch, M.A., Balke, M., 2008. Global diversity of water beetles (Coleoptera) in freshwater. Hydrobiologia 595, 419-442.

Jackson, D.J., 1952. Observations on the capacity for flight of water beetles. Proc. R. Ent. Soc. Lond. 27, 57-70.

Jackson, D.J., 1956. The capacity for flight of certain water beetles and its bearing on their origin in the western Scottish isles. Proc. Linn. Soc. Lond. 167, 76-96.

Karaman, B., Kıyak, S., Darılmaz, M.C., 2008. Faunistic study of the aquatic beetles (Coleoptera) of Trabzon province (Turkey). Mun. Ent. Zool 3, 437-446.

Katoh, K., Toh, H., 2008. Recent developments in the MAFFT multiple sequence alignment program. Brief. Bioinform. 9, 286-298.

Korkmaz, E.M., Lunt, D.H., Çıplak, B., Değerli, N., Başıüyü̈k, H.H., 2014. The contribution of Anatolia to European phylogeography: the centre of origin of the meadow grasshopper, Chorthippus parallelus. J. Biogeogr. 41, 1793-1805.

Kotlík, P., Deffontaine, V., Mascheretti, S., Zima, J., Michaux, J.R., Searle, J.B., 2006. A northern glacial refugium for bank voles (Clethrionomys glareolus). Proc. Natl. Acad. Sci. USA 103, 14860-14864.

Kullman, L., 1998. Non- analogous tree flora in the Scandes Mountains, Sweden, during the early Holocene- macrofossil evidence of rapid geographic spread and response to palaeoclimate. Boreas 27, 153-161.

Lanfear, R., Calcott, B., Ho, S.Y.W., Guindon, S., 2012. PartitionFinder: combined selection of partitioning schemes and substitution models for phylogenetic analyses. Mol. Biol. Evol. 29, 1695-1701.

Larson, D.J., 1990. Oreodytes obesus (Leconte) and O. sanmarkii (CR Sahlberg)(Coleoptera: Dytiscidae) in North America. Coleopt. Bull. 44, 295-303.

Larson, D.J., Alarie, Y., Roughley, R.E., 2000. Predaceous diving beetles (Coleoptera: Dytiscidae) of the Nearctic Region, with emphasis on the fauna of Canada and Alaska. NRC Research Press, Ottawa.

Lozek, V., 2006. Last Glacial paleoenvironments of the West Carpathians in the light of fossil malacofauna. J. Geol. Sci. Anthropozoic 26, 73-84.

Massilani, D., Guimaraes, S., Brugal, J.P., Bennett, E.A., Tokarska, M., Arbogast, R.M., Baryshnikov, G., Boeskorov, G., Castel, J.C., Davydov, S. 2016. Past 
climate changes, population dynamics and the origin of Bison in Europe. BMC Biol. 14, 93.

757

758

759

760

761

762

763

764

765

766

767

768

769

770

771

772

773

774

775

776

777

778

779

780

781

782

783

784

785

786

787

788

Mayr, E., 1970. Populations, species, and evolution: an abridgment of animal species and evolution. Harvard University Press, Harvard (MA).

Millán, A., Sánchez-Fernández, D., Abellán, P., Picazo, F., Carbonell, J.A., Lobo, J.M., Ribera, I., 2014. Atlas de los coleópteros acuáticos en la España peninsular. Ministerio de Agricultura, Alimentación y Medio Ambiente, Centro de Publicaciones, Madrid.

Nicholls, J.A., Challis, R.J., Mutun, S., Stone, G.N., 2012. Mitochondrial barcodes are diagnostic of shared refugia but not species in hybridizing oak gallwasps. Mol. Ecol. 21, 4051-4062.

Nilsson, A.N., 2001. World catalogue of insects. Volume 3: Dytiscidae (Coleoptera). Apollo Books, Stenstrup, DK.

Nilsson, A.N., Hájek, J. 2017a. A World Catalogue of the Family Dytiscidae, or the Diving Beetles ( Coleoptera , Adephaga ). Update distributed as a PDF file via Internet; version 31.I.2017; Available at: http://www.waterbeetles.eu

Nilsson, A.N., Hájek, J., 2017b. Catalogue of Palearctic Dytiscidae (Coleoptera). Update distributed as a PDF file via Internet; version 1. I. 2017. Available at: http://www.waterbeetles.eu

Nilsson, A.N., Holmen, M., 1995. Fauna Entomol. Scandinaviaca V. 32. The Aquatic Adephaga (Coleoptera) of Fennoscandia and Denmark. II. Dytiscidae. Brill, Leiden.

Nilsson, A.N., Kholin, S., 1994. The diving beetles (Coleoptera, Dytiscidae) of Sakhalin-an annotated checklist. Entomol. Tidskr. 115, 143-156.

Ponel, P., Guiter, F., Gandouin, E., Pailles, C., Rioual, P., Djamali, M., Andrieu-Ponel, V., Leydet, M., Van der Putten, N., de Beaulieu, J.L., 2016. Novel insights from coleopteran and pollen evidence into the Lateglacial/Holocene transition in Aubrac, French Massif Central. Palaeogeogr. Palaeoclimatol. Palaeoecol. 463, 83102.

Rambaut, A., Suchard, M.A., Xie, D., Drummond, A.J., 2014. Tracer v1. 6. 2014. Available at http://beast.bio.ed.ac.uk/Tracer.

Rand, A.L., 1948. Glaciation, an isolating factor in speciation. Evolution 2, 314-321.

Ribera, I., 2003. Are Iberian endemics Iberian? A case-study using water beetles of family Dytiscidae (Coleoptera). Graellsia 59, 475-502. 
Ribera, I., 2008. Chapter 15: Habitat constraints and the generation of diversity in freshwater macroinvertebrates. In: Lancaster, J., Briers, R.A. (Eds.), Aquatic Insects: Challenges to Populations. CAB International, UK, pp. 289-311.

Ribera, I., Castro, A., Díaz, J.A., Garrido, J., Izquierdo, A., Jach, M.A., Valladares, L.F., 2011. The geography of speciation in narrow-range endemics of the "Haenydra" lineage (Coleoptera, Hydraenidae, Hydraena). J. Biogeogr. 38, 502516.

Ribera, I., Castro, A., Hernando, C., 2010. Ochthebius (Enicocerus) aguilerai sp. n. from central Spain, with a molecular phylogeny of the Western Palaearctic species of Enicocerus (Coleoptera, Hydraenidae). Zootaxa 2351, 1-13.

Ribera, I., Nilsson, A.N., Vogler, A.P., 2004. Phylogeny and historical biogeography of Agabinae diving beetles (Coleoptera) inferred from mitochondrial DNA sequences. Mol. Phylogenet. Evol. 30, 545-562.

Rocchi, S., 2007. Il genere Oreodytes Seidlitz, 1887 negli Appennini. Onychium 5, 2933.

Rokas, A., Atkinson, R.J., Webster, L., Csóka, G., Stone, G.N., 2003. Out of Anatolia: longitudinal gradients in genetic diversity support an eastern origin for a circum Mediterranean oak gallwasp Andricus quercustozae. Mol. Ecol. 12, 2153-2174.

Schmitt, T., Varga, Z., 2012. Extra-Mediterranean refugia: The rule and not the exception? Front. Zool. 9, 22.

Sharp, D., 1882. On aquatic carnivorous Coleoptera or Dytiscidae. Sci. Trans. R. Dublin Soc. 2, 17-1003.

Shaverdo, H.V., Fery, H., 2006. Oreodytes shorti sp.n. from Mongolia (Coleoptera, Dytiscidae). Koleopterol. Rundschau 76, 35-42.

Silvestro, D., Michalak, I., 2012. RAxMLGUI: a graphical front-end for RAxML. Org. Divers. Evol. 12, 335-337.

Soffer, O., 1990. The Russian Plain at the last glacial maximum. In: Soffer, O., Gamble, C. (Eds.), The world at 18000 BP: volume 1, high latitudes. Unwin Hyman, London, pp. 228-252.

Sommer, R.S., Nadachowski, A., 2006. Glacial refugia of mammals in Europe: evidence from fossil records. Mamm. Rev. 36, 251-265.

Stamatakis, A., Hoover, P., Rougemont, J., 2008. A rapid bootstrap algorithm for the RAxML web-servers. Syst. Biol. 57, 758-771. 
822 Stewart, J.R., Lister, A.M., 2001. Cryptic northern refugia and the origins of the modern 823 biota. Trends Ecol. Evol. 16, 608-613.

824 Stewart, J.R., Lister, A.M., Barnes, I., Dalén, L., 2009. Refugia revisited: individualistic 825 responses of species in space and time. Proc. R. Soc. London B Biol. Sci. 277, $826 \quad 661-671$.

827 Tarnowska, E., Niedziałkowska, M., Gerc, J., Korbut, Z., Górny, M., Jędrzejewska, B., 828 2016. Spatial distribution of the Carpathian and Eastern mtDNA lineages of the 829 bank vole in their contact zone relates to environmental conditions. Biol. J. Linn. $830 \quad$ Soc. $119,732-744$.

831 Trizzino, M., Audisio, P.A., Antonini, G., Mancini, E., Ribera, I., 2011. Molecular 832 phylogeny and diversification of the "Haenydra" lineage (Hydraenidae, genus 833 Hydraena), a north-Mediterranean endemic-rich group of rheophilic Coleoptera. 834 Mol. Phylogenet. Evol. 61, 772-783.

835 Trizzino, M., Carnevali, L., De Felici, S., Audisio, P., 2013. A revision of Hydraena 836 837 species of the "Haenydra" lineage (Coleoptera, Hydraenidae). Zootaxa 3607, 1-

838 Trizzino, M., Valladares, L.F., Garrido, J., Audisio, P., 2012. Morphological reply to a 839 DNA call: a new cryptic species of Hydraena from western Europe, with a 840 complete overview of the Hydraena gracilis complex (Coleoptera:

841 Hydraenidae:“Haenydra” lineage). J. Nat. Hist. 46, 1065-1078.

842 Willis, K.J., Rudner, E., Sümegi, P., 2000. The full-glacial forests of central and 843 southeastern Europe. Quat. Res. 53, 203-213.

844 Zack, R.S., 1992. Notes on the Genus Oreodytes (Coleoptera: Dytiscidae) in the Pacific $845 \quad$ Northwest. Coleopt. Bull. 46, 151-154.

846

847

848 
851 Figure 1. Distribution of studied species of the Hydraena gracilis complex. White 852 circles, sampled localities.

853

854 Figure 2. Distribution of studied species of the Platambus maculatus complex. White 855 circles, sampled localities.

857 Figure 3. Distribution of Oreodytes sanmarkii and Oreodytes davisii in the Western

858 Palearctic. Coloured circles, sampled localities for each species, including also

859 Oreodytes alpinus and Oreodytes septentrionalis. Localities from Mongolia and Siberia 860 for $O$. sanmarkii and O. alpinus respectively are not show.

861

862 Figure 4. Phylogenetic tree of the Hydraena gracilis complex. Ultrametric tree obtained 863 with BEAST with combined nuclear and mitochondrial sequences and a partition by 864 gene. Numbers on nodes represent Bayesian posterior probabilities higher than 0.5. See 865 Table S1 for details of specimens and localities. Habitus photograph, H. gracilis (Lech 866 Borowiec).

867

868 Figure 5. Coalescence Skyline plots of A) H. gracilis; B) P. maculatus; C) Oreodytes 869 sanmarkii. Blue lines represent $95 \%$ highest probability density; horizontal axis - time 870 before present (Ma); vertical axis - effective population size (NeT).

871

872 Figure 6. Phylogenetic tree of the Platambus maculatus complex. Ultrametric tree 873 obtained with BEAST with combined nuclear and mitochondrial sequences and a 874 partition by gene. Numbers on nodes represent Bayesian posterior probabilities higher 875 than 0.5 . See Table S1 for details of specimens and localities. Habitus photographs, 876 from base to tip, north Italian from, P. maculatus "graellsi", north-Scottish form, and 877 typical $P$. maculatus (dotted lines mark the corresponding specimens).

879 Figure 7. Phylogenetic tree for studied Oreodytes species. Ultrametric tree obtained 880 with BEAST with combined nuclear and mitochondrial sequences and a partition by 881 gene. Numbers on nodes represent Bayesian posterior probabilities higher than 0.5. See 
882 Table S1 for details of specimens and localities. Habitus photographs, O. sanmarkii (L. 883 Borowiec) and O. davisii (U. Schmidt).

884

885 Figure 8. Habitus of (A) Platambus maculatus, standard form (specimen voucher 886 MNCN-AH71); (B) form "graellsi" (voucher MNCN-AI733); (C) specimen from north 887 Italy (voucher MNCN-AH191); (D) specimen from the Scottish Lochs (voucher IBE888 AI975). See Table S1 for details on the specimens, and Figs 6, S2 and S3 for the 889 phylogenetic relationships of the specimens.

890 
891 Table 1. Clock and coalescent demographic model comparisons for each group,

892 including AICM values and standard errors (SE). Best AICM value for each pair shown 893 in bold; models that failed to converge adequately in brackets or represented by a dash.

894 Differences $<2$ units were not considered significant.

895

\begin{tabular}{llcclcc} 
group & clock & AICM & SE & coalescence & AICM & SE \\
\hline H. gracilis & relaxed & {$[9076.7]$} & {$[ \pm 0.11]$} & constant & $\mathbf{6 7 0 5 . 3}$ & \pm 0.05 \\
& strict & $\mathbf{9 3 8 5 . 8}$ & \pm 0.24 & exponential & 6717.2 & \pm 0.24 \\
& & & & expansion & {$[6708.5]$} & $\pm 0.26]$ \\
P. maculatus & relaxed & $\mathbf{1 8 5 6 8 . 9}$ & \pm 0.52 & constant & - & - \\
& strict & 18596.7 & \pm 0.44 & exponential & {$[11173.9]$} & $\pm 19.20]$ \\
& & & & expansion & {$[9903.9]$} & $\pm 65.07]$ \\
O. sanmarkii & relaxed & $\mathbf{2 3 9 4 8 . 4}$ & \pm 0.87 & constant & - & - \\
& strict & 23952.8 & \pm 0.56 & exponential & 8204.6 & \pm 0.01 \\
& & & & expansion & $\mathbf{8 2 0 0 . 2}$ & \pm 0.15 \\
& & & & logistic & 8202.3 & \pm 0.13
\end{tabular}

896 